\title{
Relation between oral health and socioeconomic variables among schoolchildren aged 12 in the City of Manaus - AM
}

\author{
Lauramaris de Arruda RÉGIS-ARANHA ${ }^{1 *}$, Marcelo de Castro MENEGHIM ${ }^{2}$, Antonio Carlos PEREIRA ${ }^{3}$, \\ Nícia Marques de Almeida OLIVEIRA4 ${ }^{4}$ Gláucia Maria Bovi AMBROSANO5, Fábio Luiz MIALHE 6 \\ 1,4 Universidade do Estado do Amazonas, Escola Superior de Ciências da Saúde, Departamento do curso de Odontologia. Avenida Carvalho Leal, 1777 , Bairro Cachoeirinha. \\ CEP: 69065-001, Manaus, AM, Brazil. \\ 2,3,5,6 Universidade Estadual de Campinas, Faculdade de Odontologia de Piracicaba. Avenida Limeira, 901, Bairro Areião. CEP: 13414-903, Piracicaba, SP, Brazil. \\ E-mail: meneghim@fop.unicamp.br \\ * Corresponding author: laura regis@hotmail.com
}

\section{ABSTRACT}

Studies have shown that the age of 12 was determined as the age of global monitoring of caries for international comparisons and monitoring of disease trends. The aimed was to evaluate the prevalence of dental caries, fluorosis and periodontal condition and their relation with socioeconomic factors among schoolchildren aged twelve in the city of Manaus, AM. This study with a probabilistic sample of 661 children was conducted, 609 from public and 52 from private schools, in 2008. Dental caries, periodontal condition and dental fluorosis were evaluated. In order to obtain the socioeconomic classification of each child (high, upper middle, middle, lower middle, low and lower low socioeconomic classes), the guardians were given a questionnaire. The mean decayed teeth, missing teeth, and filled teeth (DMFT) found at age twelve was 1.89. It was observed that the presence of dental calculus was the most severe periodontal condition detected in $39.48 \%$. In relation to dental fluorosis, there was a low prevalence in the children examined, i.e., the more pronounced lines of opacity only occasionally merge, forming small white areas. The study showed a significant association of $5 \%$ among social class with dental caries and periodontal condition. In schoolchildren of Manaus there are low mean of DMFT and fluorosis, but a high occurrence of gingival bleeding.

KEYWORDS: Epidemiology, Periodontal Diseases, DMF index.

\section{Relação entre saúde bucal e as variáveis socioeconômicas em escolares de 12 anos de idade da cidade de Manaus-AM}

\section{RESUMO}

Estudos têm demonstrado que a idade de 12 anos foi determinada como a idade de monitoramento global da cárie para comparações e monitoramento das tendências das doenças internacionais. O objetivo foi avaliar a prevalência da cárie, fluorose e condição periodontal e sua relação com os fatores socioeconômicos em escolares de doze anos de idade da cidade de Manaus, AM. Estudo contando com uma amostra probabilística de 661 crianças, 609 provenientes das escolas públicas e 52 das privadas, em 2008. Cárie dentária, condição periodontal e fluorose dentária foram avaliadas. Com o objetivo de se obter a classificação socioeconômica de cada criança (alta, média superior, média, média inferior, baixa e baixa inferior classe socioeconômica), foi encaminhado aos responsáveis um questionário. A média dos dentes cariados, perdidos e obturados (CPO-D) aos doze anos de idade foi 1,89. Observou-se que a presença de cálculo dental foi a condição periodontal mais grave detectada em 39,48\%. Em relação à fluorose dentária, observou-se uma baixa prevalência nas crianças examinadas, ou seja, as linhas mais pronunciadas de opacidade ocasionalmente se fundem, formando pequenas áreas nebulosas. $\mathrm{O}$ estudo mostrou uma associação significativa de $5 \%$ entre a classe social com a cárie dentária e condição periodontal. Em escolares de Manaus há uma baixa média de CPO-D de cárie e fluorose, mas uma alta ocorrência de sangramento gengival.

PALAVRAS-CHAVE: Epidemiologia, doenças periodontais, índice CPO. 


\section{INTRODUCTION}

Countrywide epidemiological studies carried out by the Brazilian Ministry of Health show a significant reduction in the prevalence of caries at age twelve years. The mean DMFT (decayed, missing and filled teeth) in this age group was 6.65, 3.06, 2.80 and 2.1 for the years 1986, 1996, 2003 and 2010. Of the other side, on the Northern Region the prevalence was higher (Martins et al. 2005; Brasil 2005; Brasil 2012).

According to Moysés et al. (2002), the prevalence of fluorosis appears to follow a reverse trend to that of caries, with increasing rates reported worldwide. Fluorosis is an alteration in the dental enamel caused by ingestion of fluoride during the period of tooth formation presenting whitish spots until dark (Brasil 2009). The ingestion of fluoride at higher levels than recommended during tooth formation, leads to dental fluorosis in varying degrees of prevalence and severity (Silva 1999). The prevalence of fluorosis in Brazil at age 12 was $8.56 \%$ and $16.7 \%$ for the years 2003 and 2010 , respectively. There is a prevalence of fluorosis in the very mild component (Barros and Tomita 2010). In Brazil, the very mild component accounted for approximately $72 \%$ and $65 \%$ of these values for the years 2003 and 2010, respectively. For age 12 years, the highest rates were found in the Southeastern Region, $13.5 \%$ and $19.1 \%$ for studies done in those years (Brasil 2005; Brasil 2012).

Epidemiological studies from the Ministry of Health show that periodontal disease is a major public health problem in Brazil, with high level of disease confirmed among the population (Brasil 2005; Brasil 2012). Periodontal disease is an inflammatory process caused by oral bacteria that affects gingiva and bone (Löe and Brown 1991). The latest survey with children age 12 from the Ministry of Health showed $62.9 \%$ of them with healthy sextants, $11.7 \%$ with bleeding and $23.7 \%$ with calculus. The data for the Northern Region are $41.6 \%, 9.7 \%$ and $44.1 \%$, respectively. The Northern and the Northeastern Regions show the worst conditions (Brasil 2012).

Schoolchildren with more access to dental care and fluoridated products tend to brush their teeth more often and consequently show better oral health. Maltz and Silva (2001), Cimóes et al. (2007) and Meneghim et al. (2007) suggest that socioeconomic factors influence the health-disease process significantly.

According to the World Health Organization (1999), the age of 12 was determined as the age of global monitoring of caries for international comparisons and monitoring of disease trends. Thus, in many countries, is the last age at which data can be easily obtained through a reliable sample of the school system. So, the aim of this study was to evaluate the relation between oral health and socioeconomic variables among schoolchildren aged 12 years in the City of Manaus- AM.

\section{MATERIALS AND METHODS}

Manaus is the most populous city of Amazonas, about two millions population (IBGE 2010). In this study transversal with delineation by conglomerates, with schools randomly selected from a list provided by the State Department of Education, cover proportionally the number of schools, both private and public, as well as the total number of 12-year-old students enrolled in the city of Manaus, Amazonas.

There were a total of 826 schools ( 610 public and 216 private schools) and 20,592 students (18,962 and 1,630 students from public and private schools, respectively). The calculation of the sample size was done following of study of Moura (2004) using mean of DMFT of 3.31 and sampling error of $10 \%$.

The final sample had 661 students aged twelve years, randomly selected, 609 from public and 52 from private schools in the city of Manaus. The response rate was $100 \%$, and so there were no losses. The examination excluded from the survey children with serious systemic diseases, children with any kind of braces and children who were not authorized by the guardians to participate.

The children selected for the survey received an initial explanation about the brushing technique and each child was then handed a brush, floss and fluoridated toothpaste. They performed the brushing under the supervision of an Oral Health Technician in order to assist them with removing possible biofilm or food remains left on the tooth, so as to facilitate visual diagnosis.

Subsequently, the teeth were dried for 30 seconds with the aid of a portable compressor and previously sterilized gauze. Then, the epidemiological exam was carried out using a dental mirror n. 5 for each exam and a "ball point" CPI periodontal probe. The research complied with World Health Organization standardization (1999).

Data collection was performed by a single examiner previously calibrated by a Gold Standard examiner experienced in epidemiological surveys. The calibration process consisted in 4 hours of theory, 16 hours of clinical training (the experienced examiner demonstrated in two children as the tests will be performed. The examiner assessed 10 to 12 children per period, at school. Discussions between the examiner and experienced examiner in relation to clinical findings) and 4 hours of calibration exercise (the examiner and experienced examiner examined a group of 11 children and $10 \%$ of the sample to calculate the intra-examiner error were reexamined). In order to calculate the intra-examiner error, $10 \%$ of the samples were reexamined using Kappa statistics 
(Landis and Koch 1977), and the kappa value for caries, periodontal disease and dental fluorosis varied from 0.82 to 1.00. The interval between examination and reexamination was seven days. The child was examined in the schoolyard, sitting in a chair and in the daylight. The evaluation of these diseases was recorded into each individual child's record.

For the evaluation of dental caries the DMFT index (Mean Decayed, Missing, Filled, Teeth) was used. The Community Periodontal Index (CPI - percentage of children with bleeding, dental calculus and sound periodontal condition) was used to identify the presence of bleeding and dental calculus (OMS 1999). For dental fluorosis, the Thylstrup-Fejerskov Index was used (Thylstrup and Fejerskov 1978). The differential diagnosis between mild forms of dental fluorosis and nonfluoride enamel opacities origin were effected by the criteria of Russel (1961).

In order to obtain the socioeconomic classification of each child (high, upper middle, middle, lower middle, low and lower low socioeconomic classes), the guardians were given a questionnaire according to Meneghim et al. (2007).

For the statistical analysis, univariate analysis was performed in order to observe the association between the dependent variables. For the independent variables (gender, school, central region, not central region, household income, number of family members, parent's educational background and socioeconomic status), the Chi-square and Fisher exact tests were used (when one of the frequencies was less than or equal to 5). For the analysis, we considered $\alpha=0.05$ Bioestat (OR) and used the PROC FREQ of SAS 9.1 software (SAS Institute Inc, Cary, NC, USA).

This study was approved by the Ethics Committee of the School of Health Sciences/University of the State of Amazonas (Opinion N. 014/2008).

\section{RESULTS}

Table 1 show that, considering children in public and private schools, the mean DMFT index was low at aged twelve years. The percentage of caries-free schoolchildren was $35.4 \%$ of the sample. As for the components of the index, the most significant need was for decayed teeth at age 12 years in Manaus.

Regarding periodontal disease, considering the highest CPI score (Community Periodontal Index) for the age group

Table 1. Number of individuals examined (N), mean, standard deviation, confidence interval, percentage of decayed permanent teeth (D), missing (M), filled (F), percentage of children, according to the highest degree of periodontal condition, percentage of dental fluorosis, observed in school children 12 years in Manaus, Amazonas, Brazil, 2008.

\begin{tabular}{|c|c|c|c|c|c|}
\hline Variable & $\mathrm{N}$ & Mean & Standard Deviation (SD) & Confidence Interval (Cl) & Percentage (\%) \\
\hline Decayed (D) & 294 & 0.97 & 1.49 & $0.87-1.09$ & $51.3 \%$ \\
\hline Missing (M) & 96 & 0.21 & 0.60 & $0.17-0.27$ & $11.1 \%$ \\
\hline Filled (F) & 213 & 0.71 & 1.31 & $0.62-0.82$ & $37.6 \%$ \\
\hline DMF-T & 661 & 1.89 & 2.08 & $1.73-2.05$ & ---- \\
\hline DMF-T $>0$ & 427 & 2.92 & 1.92 & $1.73-2.05$ & $64.6 \%$ \\
\hline DMF-T public $>0$ & 406 & 2.92 & 1.91 & ---- & $66.7 \%$ \\
\hline DMF-T private $>0$ & 21 & 2.86 & 2.28 & ---- & $40.4 \%$ \\
\hline Sound & 53 & ---- & ---- & $5.7-9.7$ & $8.02 \%$ \\
\hline Bleeding & 342 & ---- & ---- & $48.2-55.9$ & $51.74 \%$ \\
\hline Dental Calculus & 261 & ---- & ---- & $35.8-43.2$ & $39.48 \%$ \\
\hline Excluded & 5 & ---- & ---- & $0.2-1.6$ & $0.76 \%$ \\
\hline With dental fluorosis & 103 & ---- & ---- & $13.0-18.7$ & $15.6 \%$ \\
\hline TF1 & 82 & ---- & ---- & $10.1-15.2$ & $12.4 \%$ \\
\hline TF2 & 21 & ---- & ---- & $2.0-4.9$ & $3.2 \%$ \\
\hline Without dental fluorosis & 558 & ---- & ---- & $81.3-87.0$ & $84.4 \%$ \\
\hline
\end{tabular}

$95 \% \mathrm{Cl}=$ Confidence Interval at $95 \%$. 
under study, it was observed that the presence of dental calculus was the most severe periodontal condition detected in $39.48 \%$ (Table 1 ).

In relation to dental fluorosis, there was a low prevalence in the children examined, i.e., the more pronounced lines of opacity only occasionally merge, forming small white areas (Table 1).

The socioeconomic classification was distributed as follows: Class A (high) 1.1\%, Class B (upper middle) 3.6\%, Class C (middle) $14.1 \%$, Class D (lower middle) 35.1\%, Class E (low) and $33.4 \%$ and Class F (lower low) $12.7 \%$. It is noteworthy that the value of the Minimum Wage in the United States is USD 1.256,66 per month (reference value of 01/08/2012), while in Brazil, the Minimum Wage is USD 335.64 .

The variable socioeconomic classes showed a significant association of $5 \%$ with dental caries and periodontal condition (Table 2 e 3). Since a statistically significant 5\% association between dental fluorosis and socioeconomic variables was not found, we chose not to provide their results in the Table.

\section{DISCUSSION}

A significant reduction the mean of DMFT at age twelve years were observed (Moura 2004; Roncalli 2011; Brasil 2012). However, this decline occurs unevenly in Brazil, as higher indices are usually found in the Northern and in the Northeastern Regions compared to other regions in Brazil, which can be confirmed by the high percentage of children experiencing caries, in which the decayed teeth are primarily responsible for this high index (Brasil 1988; Brasil 2005; Brasil 2012; Roncalli et al. 2012).

Importantly it was also found a prevalence of decayed teeth at age 12 years in work carried out in the Northern Region of the country in residents along the rivers Machado and Preto (Northern Region of the State of Rondônia), in Abaetetuba (State of Pará), in Rio Preto da Eva (State of Amazonas) and in Boa Vista (Capital of the State of Roraima) (Régis-Aranha et al. 2008; Silva et al. 2008; Tobias et al. 2008), which suggests difficult access to dental care services.

So, the oral health these schoolchildren showed a low mean of DMFT of 1.89 in relation to the World Health Organization, in Manaus DMFT of 3.31 (Moura 2004), as well as in relation to the Northern Region (Cangussu et al. 2001; Carvalho et al. 2010; Brasil 1996). However, the mean of DMFT was higher when compared to the results of studies in the Southeastern Region of the country (Meneghim et al. 2006; Meneghim et al. 2007; Brasil 2012). One of the possible factors that may have contributed to the reduction in the dental caries in the city of Manaus is the availability of fluoridated toothpastes in Brazil (Basting et al. 1997), as well as the influence of the Municipal School Health Program, which, despite its low coverage, provides preventive and curative treatments for children.

The children in public schools, just as children with family income less than one Minimum Wage had a significant association to having dental caries experience. This finding corroborates the results of studies by Moreira et al. (2007) and Freire et al. (2010), who found that the percentage of children with caries experience is higher among students in public schools than those in private schools. In turn, Brasil (1988) and Meneghim et al. (2007) reported higher mean of DMFT where economic conditions are worse. Moreira et al. (2007) and Rigo et al. (2011) found association between mother's educational background and dental caries. RégisAranha et al. (2008) evaluated children aged 12 in the city of Boa Vista, Roraima, and found no association between socioeconomic variables and DMFT. Peres et al. (2000), found no association between DMFT and mother's educational background in Florianópolis and Rigo et al. (2011) found no association between number of persons in family and dental caries. However, one of the major limitation of the study was has used only simple analysis.

The periodontal health in Manaus show concern because dental calculus and gingival bleeding were the most frequent. Lopes and Therrien (2008) reported that the prevention against a periodontal disease is based on the mechanical removal of plaque, mainly by brushing and flossing. Therefore, these results suggest the need for prevention programs to address this need in order to promote oral health.

The percentage of schoolchildren free from any gingivitis was very low compared to that found in the population aged 12 in the Northern Region of Brazil in 2010 (41.6\%). As for regional differences, we highlight the percentage of absence of gum disease, ranging from $41.6 \%$ in the Northern Region to $67.9 \%$ in the Southeastern Region (Brasil 2012). Comparing the results of this study with similar studies, we found that the condition of periodontal disease observed in this study was higher than those found in schoolchildren in the cities Itatiba, Goiânia and João Pessoa, 28.6\%, 23.7\% and 56.3\% of the schoolchildren presented unhealthy gingival condition, respectively (Cangussu et al. 2001; Freire et al. 2010; Claudino et al. 2011). However one of the possible factors may have contributed to the result this study in Manaus was only 20\% sample belongs to Socioeconomic Classes A, Socioeconomic Classes B or Socioeconomic Classes C.

Students in public schools had a significant association to having gingival bleeding and dental calculus, however the size sample did not appear to influence in this results. This finding corroborates the results of work carried out in Porto Alegre/ RS and Goiânia/GO, where students in the public school system had a higher experience of gingival bleeding (Maltz and 
Silva 2001; Freire et al. 2010). These results differ from the work done by Chambrone et al. (2008), which states that the presence of gingival and periodontal diseases is independent of socioeconomic classes, but is rather directly associated with poor oral hygiene.

In relation to dental fluorosis, there was a low prevalence in the children examined. This index corroborates studies that showed prevalence below 30\% (Cimóes et al. 2007; Barros and Tomita 2010; Carvalho et al. 2010). It is noteworthy that in Manaus/AM, in 2004, a low $12.4 \%$ prevalence of dental fluorosis was found at age 12 (Moura 2004). The epidemiological surveillance service recommends the monitoring of this disease, since some studies (Salas-Pereira et al. 2008; Rigo et al. 2010) show a prevalence above 30\%,

Table 2. Association by simple analysis between DMFT and Socioeconomic classes variables in Manaus, Amazonas, Brazil, 2008.

\begin{tabular}{|c|c|c|c|c|c|}
\hline Variable & $\begin{array}{c}\text { DMF-T }=0 \\
n(\%)\end{array}$ & $\begin{array}{c}\text { DMF-T >0 } \\
n(\%)\end{array}$ & $\mathrm{OR}$ & Cl (95\%) & $p$ \\
\hline \multicolumn{6}{|l|}{ Gender } \\
\hline Boys & $126(37.95 \%)$ & $206(62.05 \%)$ & 1.00 & & $0.1683^{*}$ \\
\hline Girls & $108(32.83 \%)$ & $221(67.17 \%)$ & 1.25 & $0.91-1.72$ & \\
\hline \multicolumn{6}{|l|}{ School } \\
\hline Private & $31(59.62 \%)$ & $21(40.38 \%)$ & 1.00 & & $0.0001^{*}$ \\
\hline Public & 203 (33.33\%) & $406(66.67 \%)$ & 2.95 & $1.65-5.27$ & \\
\hline \multicolumn{6}{|l|}{ Region } \\
\hline Central & $42(45.16 \%)$ & $51(54.84 \%)$ & 1.00 & & $0.0337^{\star}$ \\
\hline Not central & $192(33.80 \%)$ & $376(66.20 \%)$ & 1.61 & $1.03-2.51$ & \\
\hline \multicolumn{6}{|l|}{ Family Income } \\
\hline To 1 Minimum Wage & $119(31.07 \%)$ & $264(59.15 \%)$ & 1.56 & $1.13-2.16$ & $0.0219 *$ \\
\hline 1-3 MW & $96(40.85 \%)$ & 139 (68.93\%) & 1.48 & $0.59-2.21$ & \\
\hline Over 3 MW & $19(44.19 \%)$ & $24(55.81 \%)$ & 1.00 & & \\
\hline \multicolumn{6}{|c|}{ Number of persons in family } \\
\hline To 4 people & $101(33.11 \%)$ & 204 (66.89\%) & 1.00 & & $0.2553^{\star}$ \\
\hline More than 4 people & $133(37.36 \%)$ & $223(62.64 \%)$ & 0.83 & $0.60-1.14$ & \\
\hline \multicolumn{6}{|c|}{ Father's educational background } \\
\hline Illiterate & $6(42.86 \%)$ & $8(57.14 \%)$ & 0.88 & $0.30-2.58$ & $0.0753^{*}$ \\
\hline Basic education & $47(30.32 \%)$ & $108(69.68 \%)$ & 1.51 & $1.01-2.26$ & \\
\hline High school & $41(29.71 \%)$ & 97 (70.29\%) & 1.56 & $1.02-2.37$ & \\
\hline Higher education & $140(39.66 \%)$ & $213(60.34 \%)$ & 1.00 & & \\
\hline \multicolumn{6}{|c|}{ Mother's educational background } \\
\hline Illiterate & $1(14.29 \%)$ & $6(85.71 \%)$ & 4.22 & $0.50-35.48$ & $0.0017^{\#}$ \\
\hline Basic education & $62(34.07 \%)$ & $120(65.93 \%)$ & 1.36 & $0.93-1.98$ & \\
\hline High school & $33(23.91 \%)$ & $105(76.09 \%)$ & 2.24 & $1.43-3.51$ & \\
\hline Higher education & $138(41.32 \%)$ & $196(58.68 \%)$ & 1.00 & & \\
\hline \multicolumn{6}{|c|}{ Socioeconomic classes } \\
\hline$A$ e $B$ & $15(48.39 \%)$ & $16(51.61 \%)$ & 1.00 & & $0.0285^{\star}$ \\
\hline C e D & $126(38.77 \%)$ & $199(61.23 \%)$ & 1.48 & $0.71-3.10$ & \\
\hline E e F & $93(30.49 \%)$ & $212(69.51 \%)$ & 2.14 & $1.01-4.50$ & \\
\hline
\end{tabular}

*p value refers to chi-square test

\#p value refers to Fisher's exact test

1 Minimum Wage in Brazil (MW) - US \$ 335.64 (per month) 
not posing, however, a risk to public health. Furthermore, the proportion of individuals with its moderate and severe forms is still small (Meneghim et al. 2006; Carvalho et al. 2007).

There was no significant association between socioeconomic classes variables and dental fluorosis. This result differs from those described by Maltz and Silva (2001) and Meneghim et al. (2007), which found a relationship between parent's educational background and the presence of fluorosis. Freire et al. (2010) assessed 12-year-old students in public and private schools in Goiânia/GO and found that the frequency of fluorosis in children in private schools was higher than in children in public schools. However, Catani et al. (2007)

Table 3. Association by simple analysis between periodontal status and Socioeconomic classes variables in Manaus, Amazonas, Brazil, 2008.

\begin{tabular}{|c|c|c|c|c|c|}
\hline Variable & $\begin{array}{c}\text { Periodontal Health } \\
n(\%)\end{array}$ & $\begin{array}{c}\text { Bleeding/ Calculus } \\
n(\%)\end{array}$ & $\mathrm{OR}$ & Cl (95\%) & $\mathrm{p}$ \\
\hline \multicolumn{6}{|l|}{ Gender } \\
\hline Boys & 28 (8.54\%) & 300 (91.46\%) & 1.00 & & $0.6673^{*}$ \\
\hline Girls & $25(7.62 \%)$ & $303(92.38 \%)$ & 1.13 & $0.64-1.98$ & \\
\hline \multicolumn{6}{|l|}{ School } \\
\hline Private & $14(26.92 \%)$ & $38(73.08 \%)$ & 1.00 & & $<0.0001^{*}$ \\
\hline Public & $39(6.46 \%)$ & 565 (93.54\%) & 5.34 & $2.67-10.68$ & \\
\hline \multicolumn{6}{|l|}{ Region } \\
\hline Central & $12(12.90 \%)$ & $81(87.10 \%)$ & 1.00 & & $0.0654^{*}$ \\
\hline Not central & $41(7.28 \%)$ & $522(92.72 \%)$ & 1.89 & $0.95-3.74$ & \\
\hline \multicolumn{6}{|l|}{ Family Income } \\
\hline To 1 Minimum Wage & $29(7.61 \%)$ & $352(92.39 \%)$ & 4.17 & $1.91-9.13$ & $<0.0001^{*}$ \\
\hline 1-3 MW & $13(5.60 \%)$ & $219(94.40 \%)$ & 5.79 & $2.39-14.02$ & \\
\hline Over 3 MW & $11(25.58 \%)$ & $32(74.42 \%)$ & 1.00 & & \\
\hline \multicolumn{6}{|c|}{ Number of persons in family } \\
\hline To 4 people & 27 (8.94\%) & $275(91.06 \%)$ & 1.00 & & $0.4547^{\star}$ \\
\hline More than 4 people & $26(7.34 \%)$ & $328(92.66 \%)$ & 1.24 & $0.71-2.17$ & \\
\hline \multicolumn{6}{|c|}{ Father's educational background } \\
\hline Illiterate & $2(14.29 \%)$ & $12(85.71 \%)$ & 0.69 & $0.15-3.19$ & $0.0779 \#$ \\
\hline Basic education & $8(5.23 \%)$ & $145(94.77 \%)$ & 2.07 & $0.94-4.57$ & \\
\hline High school & 7 (5.11\%) & $130(94.89 \%)$ & 2.12 & $0.92-4.89$ & \\
\hline Higher education & $36(10.26 \%)$ & $315(89.74 \%)$ & 1.00 & & \\
\hline \multicolumn{6}{|c|}{ Mother's educational background } \\
\hline Illiterate & $0(0.00 \%)$ & $7(100.00 \%)$ & - & - & $0.1585 \#$ \\
\hline Basic education & $10(5.56 \%)$ & 170 (94.44\%) & 2.00 & $0.97-4.15$ & \\
\hline High school & $8(5.84 \%)$ & $129(94.16 \%)$ & 1.90 & $0.86-4.21$ & \\
\hline Higher education & $35(10.54 \%)$ & $297(89.46 \%)$ & 1.00 & & \\
\hline \multicolumn{6}{|c|}{ Socioeconomic classes } \\
\hline$A$ e $B$ & $8(25.81 \%)$ & $23(74.19 \%)$ & 1.00 & & $0.0006^{*}$ \\
\hline C e D & $27(8.36 \%)$ & $296(91.64 \%)$ & 3.81 & $1.56-9.34$ & \\
\hline E e F & 18 (5.96\%) & 284 (94.04\%) & 5.49 & $2.15-13.98$ & \\
\hline
\end{tabular}

* $p$ value refers to chi-square test

\# $p$ value refers to Fisher's exact test

1 Minimum Wage on Brazil (MW) - US \$ 335.64 (per month) 
has demonstrated an association between a single indicator of socioeconomic classes (possession of a car) and fluorosis.

\section{CONCLUSION}

The findings from this study suggest that more than half of the students were free from caries, a small percentage had dental fluorosis and $91.98 \%$ of the samples showed bleeding and dental calculus. There was a significant association between variables type of school attended (public) with dental caries and periodontal condition, however the size sample did not appear to influence in this results. This index can be reduced with the implementation of preventive measures, considering that the most serious conditions were calculus and bleeding. The planning, improvement and aiming of activities related to oral health done by municipal and state administrations are necessary measures to improve the quality of health oral of the population. The data provided herein may be added to those already known by the respective authorities in order to facilitate the delivery of basic oral health services to the population.

\section{ACKNOWLEDGMENTS}

We wish to thank the Fundação de Amparo à Pesquisa do Estado do Amazonas (Research Support Foundation of the State of Amazonas -FAPEAM). Grant number: 003/2008 granted to the first author.

\section{REFERENCES}

Barros, B.S.A.; Tomita, N.E. 2010. Aspectos epidemiológicos da fluorose dentária no Brasil: pesquisas no período 1993-2006. Ciência \& Saúde Coletiva, 15: 289-300.

Basting, R.T.; Pereira, A.C.; Meneghim, M.C. 1997. Avaliação da prevalência de cárie dentária em escolares do município de Piracicaba, SP, Brasil, após 25 anos de fluoretação das águas de abastecimento público. Revista de Odontologia da Universidade de São Paulo, 11: 287-92.

Brasil. 1988. Levantamento Epidemiológico em Saúde Bucal - Parte 1: Brasil, zona urbana, 1986. http://dab.saude.gov.br/cnsb/ vigilancia.php. Acesso em 13/01/2014.

Brasil. 1996. Levantamento Epidemiológico em Saúde Bucal 1996. Cárie Dental. http://tabnet.datasus.gov.br/cgi/sbucal/sbdescr. htm. Acesso em 18/08/2013.

Brasil. 2005. Condições de Saúde Bucal da população brasileira 2002 - 2003. Resultados principais. http://dtr2001.saude.gov. br/editora/produtos/livros/pdf/05_0053_M.pdf. Acesso em 13/01/2014.

Brasil. 2009. SB Brasil 2010 - Pesquisa Nacional de Saúde Bucal. Projeto técnico. http://dab.saude.gov.br/CNSB/sbbrasil/ arquivos/Projeto_SB2010_VersaoFinal.pdf. Acesso em $13 / 01 / 2014$.

Brasil. 2012. SB Brasil 2010 - Pesquisa Nacional de Saúde Bucal. Resultados principais. http://bvsms.saude.gov.br/bvs/ publicacoes/pesquisa_nacional_saude_bucal.pdf. Acesso em $13 / 01 / 2014$

Cangussu, M.C.T.; Coelho, E.O.; Castellanos Fernandes, R.A. 2001. Epidemiologia e iniquidade em saúde bucal aos 5, 12 e 15 anos de idade no município de Itatiba, São Paulo. Revista da Faculdade de Odontologia de Bauru, 9: 77-85.

Carvalho, R.W.F.; Valois, R.B.V.; Santos, C.N.A.; Marcellini, O.S.; Bonjardim, L.R.; Oliveira, C.C.C.; et al. 2010. Estudo da prevalência de fluorose dentária em Aracaju. Ciência \& Saúde Coletiva, 15: 1875-80.

Carvalho, T.S.; Kehrle, H.M.; Sampaio, F.C. 2007. Prevalence and severity of dental fluorosis among students from João Pessoa, PB, Brazil. Brazilian Oral Research, 21: 198-203.

Catani, D.B.; Hugo, F.N.; Cypriano, S.; Sousa, M.L.R.; Cury, J.A. 2007. Relação entre níveis de fluoreto na água de abastecimento público e fluorose dental. Revista de Saúde Pública, 41: 732-9.

Chambrone, L.; Lima, L.A.P.A.; Chambrone, L.A. 2008. Prevalência das Doenças Periodontais no Brasil. Parte II. 1993-2003. Revista Odonto, 16: 69-76.

Cimôes, R.; Júnior, A.F.C.; Souza, E.H.A.; Gusmão, E.S. 2007. Influência da classe social nas razóes clínicas das perdas dentárias. Ciência \& Saúde Coletiva, 12: 1691-6.

Claudino, L.V.; Alexandria, A.K.F.; Lima, A.L.; Silva, N.B.; Dantas, R.V.F.; Santiago, B.M.; et al. 2011. Condições de Saúde Bucal, Acesso aos Serviços Odontológicos e Autopercepçáo de Saúde Bucal em Escolares de 12 anos. Pesquisa Brasileira em Odontopediatria e Clínica Integrada, 11: 573-84.

Freire, M.C.M.; Reis, S.C.G.B.; Gonçalves, M.M.; Balbo, P.L.; Leles, C.R. 2010. Condição de saúde bucal em escolares de 12 anos de escolas públicas e privadas de Goiânia, Brasil. Revista Panamericana de Salud Pública, 28: 86-91.

IBGE. 2010. Censo Demográfico. http://www.censo2010.ibge. gov.br/sinopse/index.php?dados $=210 \& u f=13$. Acesso em $19 / 08 / 2013$

Landis, J.R.; Koch, G.G. 1977. The measurement of observer agreement for categorical data. International Biometric Society, 33: $159-74$.

Lopes, I.R.; Therrien, S.M.N. 2008. Prevalência de gengivite em crianças brasileiras: estudos acerca do tema. Revista da Associação Brasileira de Odontologia Nacional, 16: 34-8.

Löe, H.; Brown, J.L. 1991. Early onset periodontitis in the United States of America. Journal of Periodontology, 62: 608-16.

Maltz, M.; Silva, B.B. 2001. Relação entre cárie, gengivite e fluorose e nível socioeconômico em escolares. Revista de Saúde Pública, 35: $170-6$

Martins, A.M.E.B.L.; Melo, F.S.; Fernandes, F.M.; Sorte, J.A.B.; Coimbra, L.G.A.; Batista, R.C. 2005. Levantamentos epidemiológicos brasileiros das condições de saúde bucal. Unimontes Cientifica, 7: 55-66.

Meneghim, M.C.; Tagliaferro, E.P.S.; Tengan, C.; Meneghim, Z.M.A.P.; Pereira, A.C.; Ambrosano, G.M.B.; et al. 2006. Trends in caries experience and fluorosis prevalence in 11 to 12 yearold brazilian children between 1991 and 2004. Oral Health of Preventive Dentistry, 4: 193-8. 
Meneghim, M.C.; Kozlowski, F.C.; Pereira, A.C.; Ambrosano, G.M.B.; Meneghim, Z.M.A.P. 2007. Classificaçáo socioeconômica e sua discussão em relação à prevalência de cárie e fluorose dentária. Ciência \& Saúde Coletiva, 12: 523-9.

Moreira, P.V.L.; Rosenblatt, A.; Passos, I.A. 2007. Prevalência de cárie em adolescentes de escolas públicas e privadas na cidade de João Pessoa, Paraíba, Brasil. Ciência \& Saúde Coletiva, 12: 1229-36.

Moura, R.N.V. 2004. Análise da prevalência de cárie e fluorose dentária em escolares do município de Manaus - AM. Dissertação de Mestrado, Universidade Federal do Amazonas/ Faculdade de Ciências da Saúde, Manaus, Amazonas. 104p.

Moysés, S.J.; Moysés, S.T.; Allegretti, A.C.V.; Argenta, M.; Werneck, R. 2002. Fluorose dental: ficção epidemiológica? Revista Panamericana de Salud Pública, 12: 339-46.

Organização Mundial de Saúde. 1999. Levantamentos básicos em saúde bucal. 4ta ed. Editora Santos, São Paulo, 1999, 65p.

Peres, K.G.A.; Bastos, J.R.M.; Latorre, R.D.O. 2000. Severidade de cárie em crianças e relação com aspectos sociais e comportamentais. Revista de Saúde Pública, 34: 402-8.

Régis-Aranha, L.A.; Rebelo, M.A.B.; Souza, S.M.F.M.; Parente, R.C. 2008. Cárie dentária em escolares de 12 anos de idade de Boa Vista, Roraima, Brasil. Cadernos de Saúde Pública, 24: 2449-50.

Rigo, L.; Junior, A.F.C.; Souza, E.A.; Abegg, C.; Lodi, L. 2010. Estudo sobre a fluorose dentária num município do Sul do Brasil. Ciência \& Saúde Coletiva, 15: 1439-48.

Rigo, L.; Caldas Júnior, A. F.; Souza, E. H. A. 2011. Experiência de Cárie Dentária e Fatores Associados em Escolares de um Município com Fluoretação na Água. Pesquisa Brasileira em Odontopediatria e Clinica Integrada, 11: 407-15.
Roncalli, A.G. 2011. Projeto SB Brasil 2010 - Pesquisa Nacional de Saúde Bucal revela importante redução da cárie dentária no país. Cadernos de Saúde Pública, 27: 4-5.

Roncalli, A.G.; Côrtes, M.I.S.; Peres, K.G. 2012. Perfis epidemiológicos de saúde bucal no Brasil e os modelos de vigilância. Cadernos de Saúde Pública, 28: 58-68.

Russel, A.L. 1961. The diferential diagnosis of fluoride and nonfluoride enamel opacities. Journal of Public Health Dentistry, 21: 143-6.

Salas-Pereira, M.T.; Beltrán-Aguilar, E.D.; Chavarría, P.; Solórzano, I.; Horowitz, H. 2008. Enamel fluorosis in 12 and 15-year-old school children in Costa Rica. Results of a National Survey, 1999. Community Dental Health, 25: 178-84.

Silva, M.F.A. 1999. Flúor sistêmico: aspectos básicos, toxicológicos e clínicos. In: Kriger, L. (Ed.). Promoção de Saúde Bucal. Artes Médicas, São Paulo, p. 143-65.

Silva, R.H.A.; Castro, R.F.M.; Cunha, D.C.S.; Almeida, C.T.; Bastos, J.R.M.; Camargo, L.M.A. 2008. Cárie dentária em população ribeirinha do Estado de Rondônia, Regiáo Amazônica, Brasil, 2005/2006. Cadernos de Saúde Pública, 24: 2347-53.

Thylstrup, A.; Fejerskov, O. 1978. Clinical appearance of dental fluorosis in permanent teeth in relation to histologic changes. Community Dentistry and Oral Epidemiology, 6: 315-28.

Tobias, R.; Parente, R.C.P.; Rebelo, M.A.B. 2008. Prevalência e gravidade da cárie dentária e necessidade de tratamento em crianças de 12 anos de município de pequeno porte inserido no contexto amazônico. Revista Brasileira de Epidemiologia, 11: 608-18.

Recebido em 31/10/2013

Aceito em 16/02/2014 